\title{
21. MINERALOGY OF ALTERED BASAL VOLCANICLASTIC SEDIMENTS AT SITES 447 (WEST PHILIPPINE BASIN) AND 450 (PARECE VELA BASIN), DEEP SEA DRILLING PROJECT LEG 59
}

\author{
Renzo Sartori and Luciano Tomadin, Laboratorio di Geologia Marina, Consiglio Nazionale delle Ricerche, \\ 40127 Bologna, Italy
}

\begin{abstract}
The authigenic minerals contained in the altered basal intervals of volcaniclastic sediments from Sites 447 and 450 of Deep Sea Drilling Project Leg 59 are dioctahedral smectite (with variable crystallinity), phillipsite, and sanidine. Sanidine seems the most widespread and common product of basal alteration in the Philippine Sea marginal basins. The neomorphic mineral suites may have been produced by (1) halmyrolisis of the volcaniclastic sediments; (2) halmyrolisis of the underlying basalts; or (3) hydrothermalism associated with basaltic intrusions.

At Site 450, other authigenic minerals occur (carbonates, analcime, clinoptilolite, Fe-Mn oxides), and the basal paragenesis is consistent with a hydrothermal origin. Such a process could have produced temperatures up to $200^{\circ} \mathrm{C}$ in the tuffs lying as much as 2 meters above the contact with a basaltic intrusion. Products of low-temperature alteration, however, are also present in the altered interval of this site.
\end{abstract}

\section{INTRODUCTION}

The basal sediments lying immediately above a series of basalt flows are commonly altered and often metalrich, and can be produced either (1) by hydrothermalism, which may or may not be associated with former spreading centers (Bonatti, 1975), or (2) by sea-water alteration (halmyrolisis) of the basaltic basement (Hummel, 1922; Natland, 1973). Alteration of basal sediments has been studied in recent years utilizing numerous samples from DSDP sites, but pertinent data from marginal back-arc basins are relatively scarce (Bonatti et al., 1978).

This chapter studies the mineralogy of the altered intervals of volcaniclastic sequences cored during DSDP Leg 59 at Sites 447 and 450 in the Philippine Sea complex of marginal basins (Fig. 1). The purpose is to give a detailed account of the suites of neomorphic minerals and to discuss their possible genetic processes.

\section{METHODS}

We analyzed powders of bulk samples and oriented slides of clay minerals ( $<2-\mu \mathrm{m}$ fraction) with a Philips X-ray diffractometer, using the $\mathrm{CuK}_{\alpha}$ and $\mathrm{FeK}_{\alpha}$ radiations and a goniometer speed of $1^{\circ} 2 \theta$ per minute. Quantitative estimates of the amorphous and mineral fractions were performed following the procedures given by Cook et al. (1975), but our mineral percentages are calculated on the whole sample (i.e., amorphous matter $+\mathrm{X}$-ray diffractive minerals $=100$ ). The analytic results are reported in Table 1 . All samples also have been studied by optical microscopy on smear slides, and some of them have been examined with the scanning electron microscope (SEM).

\section{SITE 447}

Hole 447A was drilled in the West Philippine Basin (Fig. 1). A total of 113 meters of sediments was cored before encountering the basaltic basement. The sedimentary column contains, from the mudline core downward:

1) 37.5 meters of a barren, dark brown pelagic clay (Cores 1-4);
2) 9.5 meters of middle-upper Oligocene calcareous pelagic clay (Core 5);

3) 38.0 meters of middle Oligocene carbonate-bearing ruditic units, comprising tuffaceous volcaniclastic breccias and polymictic breccias (Cores 6-9);

4) 2.1 meters of barren, altered, very fine tuff or mudstone, in variegated layers 8 to $40 \mathrm{~cm}$ thick with shades of gray, brown, olive, olive gray, and grayish green (Core 10, Section 1 and part of Section 2);

5) 25.9 meters of middle Oligocene tuffs and volcaniclastic breccias and/or conglomerates (Core 10, part of Section 2, through Core 13).

Beneath this unit, the basaltic basement has been cored down to a total sub-bottom depth of 296.5 meters (Cores 14-36).

We analyzed samples from the variegated, altered tuffs of the upper part of Core 10. Apart from the variable colors, these are rather monotonous deposits, which show only diffuse mottling in shades slightly lighter or darker than the background. Seven samples have been taken at each major color change. Figure 2 shows X-ray mineralogy by mineral graphs.

The amorphous fraction ranges from $68 \%$ to $84 \%$. The X-ray mineral fraction contains dioctahedral smectite of the beidellite-montmorillonite group, phillipsite, and sanidine. Minor amounts of aragonite crystals and iron-manganese amorphous oxides and hydroxides have been detected on smear slides. Phillipsite appears only in the two lowest samples, close to the bottom of the altered zone. In phillipsite-bearing samples, the amorphous fraction is low and the smectite decreases in amount (from $5-12 \%$ to $1-2 \%$ ) and in crystallinity ( $\mathrm{v} / \mathrm{p}$ ratio from $>0.5$ to $<0.5$ ). Sanidine approaches the theoretical composition (almost pure monoclinic K-feldspar) and is fairly constant $(6-12 \%)$ throughout Core 10.

All these minerals seem to derive from the alteration of a previous unit rich in volcanic glass. However, our 


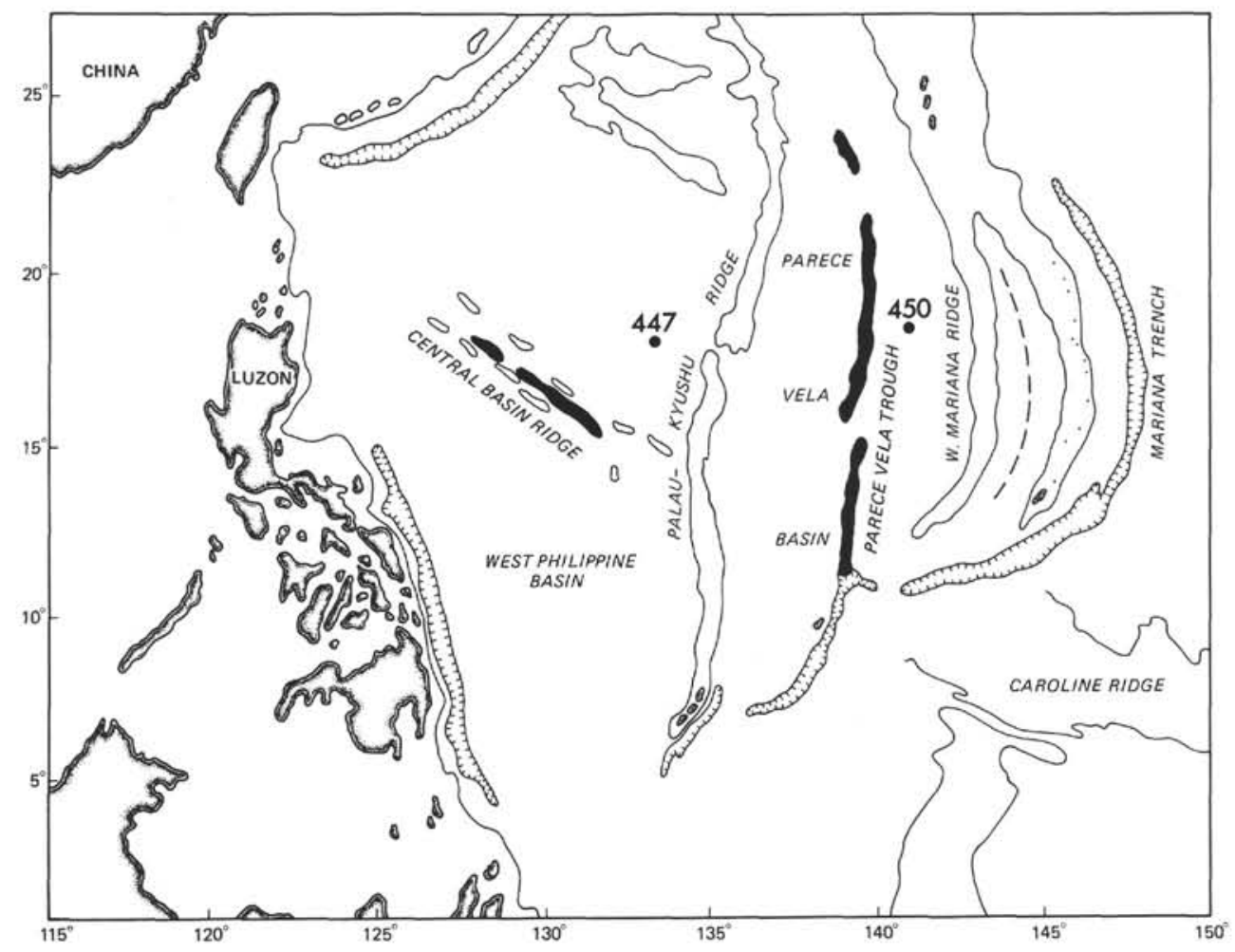

Figure 1. Schematic location map of the marginal basins of the Philippine Sea with locations of the sites studied in this chapter.

Table 1. Quantitative X-ray mineralogy of the analyzed samples.

\begin{tabular}{|c|c|c|c|c|c|c|c|c|c|c|}
\hline \multirow[b]{2}{*}{$\begin{array}{c}\text { Sample } \\
\text { (intervals in } \mathrm{cm} \text { ) }\end{array}$} & \multirow{2}{*}{ 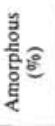 } & \multicolumn{2}{|c|}{ Smectite } & \multirow{2}{*}{$\begin{array}{l}\frac{\tilde{g}}{\mathrm{~g}} \\
\frac{\vec{g}}{2} \\
\frac{\pi}{2}\end{array}$} & \multirow[b]{2}{*}{ 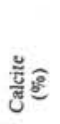 } & \multirow{2}{*}{ 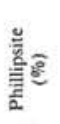 } & \multirow{2}{*}{ 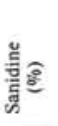 } & \multirow{2}{*}{ 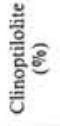 } & \multirow{2}{*}{ 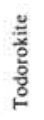 } & \multirow{2}{*}{ 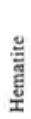 } \\
\hline & & है & $\frac{\sqrt[a]{a}}{3}$ & & & & & & & \\
\hline $447 \mathrm{~A}-10-1,18-20$ & 84 & 8.0 & 0.61 & 0.0 & 0.0 & 0.0 & 8.0 & 0.0 & - & - \\
\hline $447 \mathrm{~A}-10-1,33-34$ & 80 & 8.8 & 0.56 & 0.0 & 0.0 & 0.0 & 11.2 & 0. & - & - \\
\hline $447 \mathrm{~A}-10-1,62-64$ & 82 & 6.2 & 0.55 & 0.0 & 0.0 & 0.0 & 11.8 & 0. & - & - \\
\hline 447A-10-1, 87-89 & 84 & 5.5 & 0.47 & 0.0 & 0.0 & 0.0 & 10.5 & 0.0 & - & - \\
\hline $447 \mathrm{~A}-10-1,101-104$ & 77 & 12.3 & 0.50 & 0.0 & 0.0 & 0.0 & 10.7 & 0.0 & - & - \\
\hline $447 \mathrm{~A}-10-1,128-130$ & 68 & 1.8 & 0.36 & 0.0 & 0.0 & 22.0 & 8.3 & 0.0 & - & - \\
\hline $447 \mathrm{~A}-10-2,40-42$ & 83 & 1.5 & 0.45 & 0.0 & 0.0 & 10.3 & 5.2 & 0.0 & - & - \\
\hline $450-35-1,106-109$ & 79 & 4.5 & 0.67 & 9.7 & 6.7 & 0.0 & 0.0 & 0.0 & - & - \\
\hline $450-35-2,69-75$ & 77 & 4.5 & 0.72 & 16.2 & 2,3 & 0.0 & 0.0 & 0. & - & - \\
\hline $450-35-3,0-4$ & 76 & 4.7 & 0.70 & 19.2 & 0.0 & 0.0 & 0.0 & 0.0 & - & - \\
\hline $450-35-3,8-10$ & 68 & 2.3 & 0.66 & 29.7 & 0.0 & 0.0 & 0.0 & 0.0 & - & - \\
\hline $450-35-3,18-24$ & 81 & 3.9 & 0.65 & 15.1 & 0.0 & 0.0 & 0.0 & 0.0 & - & - \\
\hline $450-35-3,37-40$ & 85 & 2.8 & 0.74 & 12.2 & 0.0 & 0.0 & 0.0 & 0.0 & - & - \\
\hline $450-35-3,46-49$ & 82 & 2.4 & 0.74 & 14.2 & 1.4 & 0.0 & 0.0 & 0.0 & - & - \\
\hline $450-35-3,51-54$ & 82 & 2.3 & 0.64 & 15.7 & 0.0 & 0.0 & 0.0 & 0.0 & - & \\
\hline $450-35-3,59-63$ & 86 & 2.5 & 0.53 & 11.5 & 0.0 & 0.0 & 0.0 & 0.0 & + & - \\
\hline $450-35-3,64-67$ & 83 & 2.7 & 0.59 & 12.5 & 0.0 & 0.0 & 0.0 & 1.8 & ++ & - \\
\hline $450-35-3,68-70$ & 88 & 1.8 & 0.58 & 10.2 & $0 .($ & 0.0 & 0.0 & 0.0 & - & - \\
\hline $450-35-3,76-79$ & 88 & 4.8 & 0.66 & 7.3 & 0.0 & 0.0 & 0.0 & 0.0 & - & - \\
\hline $450-35-3,89-91$ & 89 & 1.2 & 0.64 & 9.0 & 0.0 & 0.0 & 0.0 & 0.8 & + & \\
\hline $450-36-1,5-8$ & 83 & 4.7 & 0.61 & 3.3 & 0.0 & 0.0 & 9.0 & 0.0 & - & \\
\hline $450-36-1,70-76$ & 80 & 5.4 & 0.67 & tr. & 9.0 & 0.0 & 5. & 0.0 & - & \\
\hline $450-36-1,115-119$ & 84 & 1.7 & 0.35 & tr. & 10.7 & 1.6 & 1.9 & 0.0 & - & \\
\hline $450-36-2,5-8$ & 81 & 2.9 & 0.43 & 0.0 & 6.2 & 3.0 & 6.9 & 0.0 & - & - \\
\hline $450-36-2,34-37$ & 76 & 3.5 & 0.42 & 0.0 & 0.0 & 13.9 & 6.6 & 0.0 & - & \\
\hline $450-36-2,82-85$ & 84 & 2.8 & 0.41 & 0.0 & 0. & 6.1 & 7.1 & 0.0 & - & \\
\hline $450-36-2,103-10$ & 78 & 2.5 & 0.42 & 0.0 & 0.0 & 13.9 & 5.6 & 0.0 & - & \\
\hline $450-36-2,10$ & 83 & 1.0 & 0.40 & 0.0 & 0.0 & 11.4 & 4.7 & 0.0 & - & \\
\hline $450-36-2,112-115$ & 87 & 1.5 & 0.57 & 0.0 & 0.0 & 4.8 & 6.7 & 0.0 & - & \\
\hline
\end{tabular}

Note: $-=$ absence, $+=$ presence, $++=$ relative abundance.

$a_{v / p}=$ smectite crystallinity according to Biscaye, 1965.

sampling was confined only to the altered zone, so that we cannot exclude the possibility that sanidine and smectite were at least in part already present as components of the volcaniclastic host rock.

\section{SITE 450}

Hole 450 was drilled in the eastern half of the Parece Vela Basin (Fig. 1). Its sedimentary column is represented, from the mudline core down to a sub-bottom depth of 333 meters, by:

1) 26.5 meters of Pleistocene to upper Miocene dark brown, ash-bearing pelagic clay (Sub-unit la, Cores 1-3);

2) 61.5 meters of upper to middle Miocene ash-rich pelagic clay with minor dark gray ash layers (Sub-unit $1 \mathrm{~b}$, Cores 4 through 10 );

3) 236.5 meters of a middle Miocene turbiditic sequence of dark gray vitric and/or crystal tuffs, fine vitric tuffs, and tuffaceous volcaniclastic conglomerates, all altered in varying degrees to clay minerals and with nannofossil-bearing hemipelagic layers (Sub-unit $2 \mathrm{a}$, Cores 10 through the top of 35 );

4) 8.5 meters of barren, vitric tuff and fine tuff, altered to various shades of reddish brown (Sub-unit $2 b$, lowermost Core 35 and uppermost 36 ). Except for the color change, the depositional characteristics are exactly the same as those of Sub-unit 2a.

5) 0.01 meters of thermally and chemically metamorphosed pale yellowish white fine vitric tuff (Sub-unit 2c, part of Core 36 ).

This sequence rests on a pillowed intrusive plagioclase-olivine phyric basalt, drilled to a total sub-bottom depth of 340 meters. 


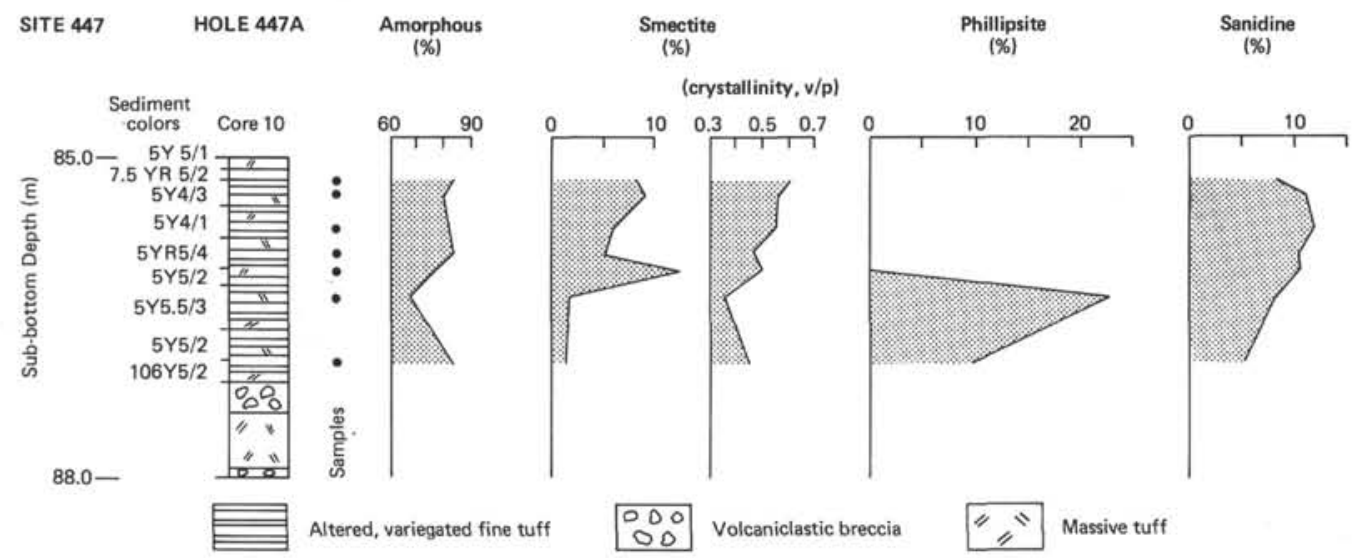

Figure 2. X-ray mineral graphs for Core 10 of Hole 447A. (To the left of the lithologic column, sediment colors are indicated by using the standard shipboard color chart system. Smectite crystallinity $[\mathrm{v} / \mathrm{p}]$ is measured according to Biscaye, 1965.)

We have analyzed a total of 22 samples from the lowermost portion of the unaltered Sub-unit $2 a$ and from the whole Sub-unit $2 \mathrm{~b}$. The detailed X-ray mineralogy is shown by mineral graphs in Figure 3.

\section{Sub-unit 2a (Samples 35-1, 106-109 cm to 35-3, $46-49 \mathrm{~cm}$ of Table 1)}

The vitric tuffs of this unaltered interval contain 68 to $85 \%$ amorphous matter, and the X-ray diffractive fraction is given by scarce dioctahedral smectite (the same as Hole 447A) with fair to high crystallinity ( $v / p$ ratio $0.6-0.7)$, by abundant plagioclase $(10-30 \%$, An $>60$ ), and by occasional calcite. The calcite is biogenic (skeletons of nannofossils), low in magnesium, and is contained in hemipelagic layers that are sometimes burrowed and mottled. At places, layers of crystal vitric tuff occur in the sequence (e.g., Sample 35-3, 8-10 $\mathrm{cm})$. These have lower amorphous and higher plagioclase contents than do vitric tuffs. Biogenic calcite and plagioclase represent primary components of these submarine turbiditic tuffs; the latter are crystals ejected with glass by subaerial and/or submarine explosions

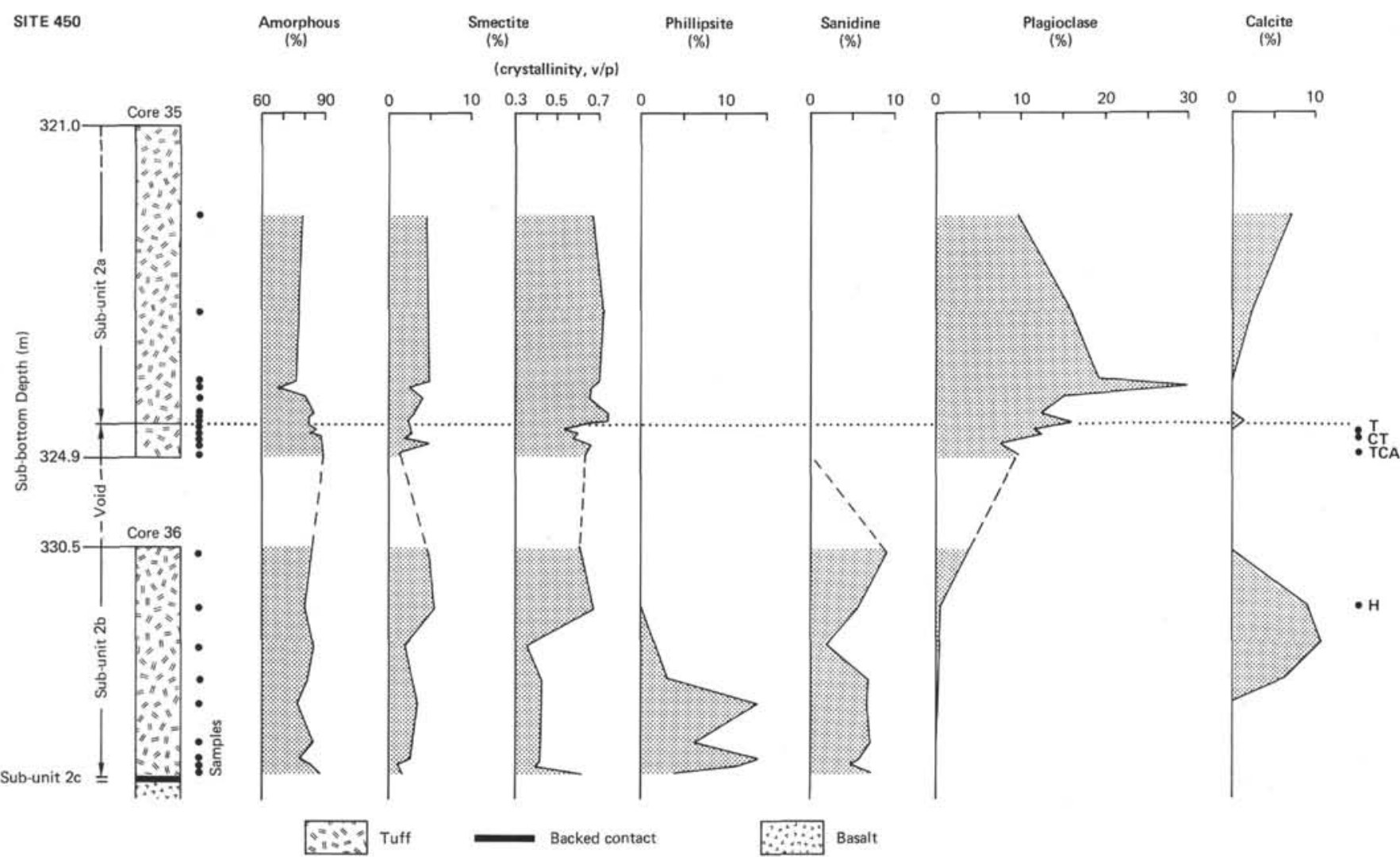

Figure 3. X-ray mineral graphs for the basal interval of Site 450. (The horizontal dotted line marks the boundary between unaltered [Sub-unit 2a] and altered [Sub-unit 2b] tuffs. A-aragonite; T-todorokite; H-hematite; C-clinoptilolite.) 
associated with arc volcanism. Smectite contents fluctuate with the amorphous fraction and derive from devitrification of glass.

\section{Upper Portion of Sub-unit 2b (Samples 35-3, 51-54 cm to $35-3,89-91 \mathrm{~cm}$ of Table 1 )}

Just below the major color change to red-brown shades, the amorphous fraction slightly increases to more than $85 \%$. This is probably related to the addition of amorphous iron-manganese compounds over the volcanic glass background. Plagioclase significantly decreases $(7-12 \%)$ and smectite crystallinity is slightly less than in Sub-unit $2 \mathrm{a}(\mathrm{v} / \mathrm{p}$ ratio 0.5-0.6). Todorokite is present in some layers, concentrated in black blebs, streaks, and mottles. Clinoptilolite occurs occasionally, amounting to about $2 \%$ in Sample $35-3,59-63 \mathrm{~cm}$. Aragonite, not detected by X-ray diffraction, occurs in some smear slides as platelets, twins, and radiating crystals. Most of these are euhedral, but some have small etching pits and scars. Calcite is virtually absent in this interval, even in hemipelagic layers, which suggests a possible leaching of biogenous carbonate remains.

\section{Lower Portion of Sub-unit 2b (Samples 36-1, 5-8 cm to $36-2,112-115 \mathrm{~cm}$ of Table 1)}

The amorphous fraction is around $80 \%$ throughout this interval. A strong decrease in smectite crystallinity (v/p from 0.6 to 0.3-0.4) occurs below Sample 36-1, $70-76 \mathrm{~cm}$. Phillipsite appears in correspondence with such a decrease and is inversely correlated with the amorphous fraction. A few euhedral to subhedral analcime crystals have been detected by SEM in the lowermost samples of this interval. Plagioclase further decreases (less than 5\%) and eventually disappears completely below Sample 36-1, 70-76 cm. Euhedral to subhedral, almost pure sanidine appears from the top sample of this interval in concentrations of 5 to $10 \%$. Biogenic calcite is absent, but limpid lumps and clusters of recrystallized low-Mg calcite are abundant from Sample 36-1, 70-76 cm to Sample 36-2, 5-8 cm. Rare aragonite (?) crystals have also been observed on smear slides. Hematite has been found by X-ray diffraction only in sample $36-1,70-76 \mathrm{~cm}$, although amorphous iron-manganese oxides and hydroxides are widespread in smear slides from the whole Sub-unit $2 b$.

\section{DISCUSSION}

The altered basal volcaniclastic sediments at Sites 447 and 450 contain authigenic smectite, phillipsite, and sanidine. At Site 450 only, other types of authigenic zeolites and carbonates occur. All these minerals represent common products of submarine alteration of tuffs, as recognized in numerous previously studied DSDP sites. Authigenic sanidine, however, seems widespread in the Leg 59 sites, whereas reports of this mineral from other oceanic areas are few (see references in Kastner and Stonecipher, 1978).

Submarine alteration of a given host rock depends on composition of interstitial water, age, and temperature (Hay, 1978). This means that different causes can produce the same diagenetic minerals. From a general view- point, the eventual products of alteration of basal volcaniclastic sediments can derive from (1) halmyrolisis of the volcaniclastic sediments, (2) halmyrolisis of the underlying basaltic basement, and (3) hydrothermalism (up to $300-400^{\circ} \mathrm{C}$ ) associated with the emplacement of the basaltic basement.

Core evidence for the cause of the basal alteration in Hole 447A is rather poor. In Site 450, on the contrary, such causes can be assumed with some confidence; our discussion will therefore be confined to this site. Petrographic evidence (the basaltic basement is pillowed and altered) and the intrusive contact still preserved in the baked tuffs of Sub-unit $2 \mathrm{c}$ show that the basalt was emplaced and cooled beneath a few-meters-thick sequence of previously deposited tuffs. Hajash (this volume) has found that the chemical composition of the altered tuffs is consistent with hydrothermal alteration, even if a low-temperature overprint is present. These tuffs thus would have experienced, at least during the initial stages of alteration, temperatures significantly higher than those of normal deep-sea environments. The host rock unaffected by hydrothermal alteration is represented by the unaltered tuffs of Sub-unit 2a. In fact, all of Unit 2 (Cores 10 through 36 ) shows great textural and depositional uniformity, and we can reasonably assume that the basal altered interval had the same composition as the overlying unaltered section prior to the basalt intrusion and associated hydrothermalism. The range of minerals found in the host rock and in the altered interval is schematically reported in Figure 4. We will discuss separately the possible significance of different mineral groups.

\section{Plagioclase}

Calcium-rich plagioclase, which is a primary crystalline component of the host rock, decreases across the

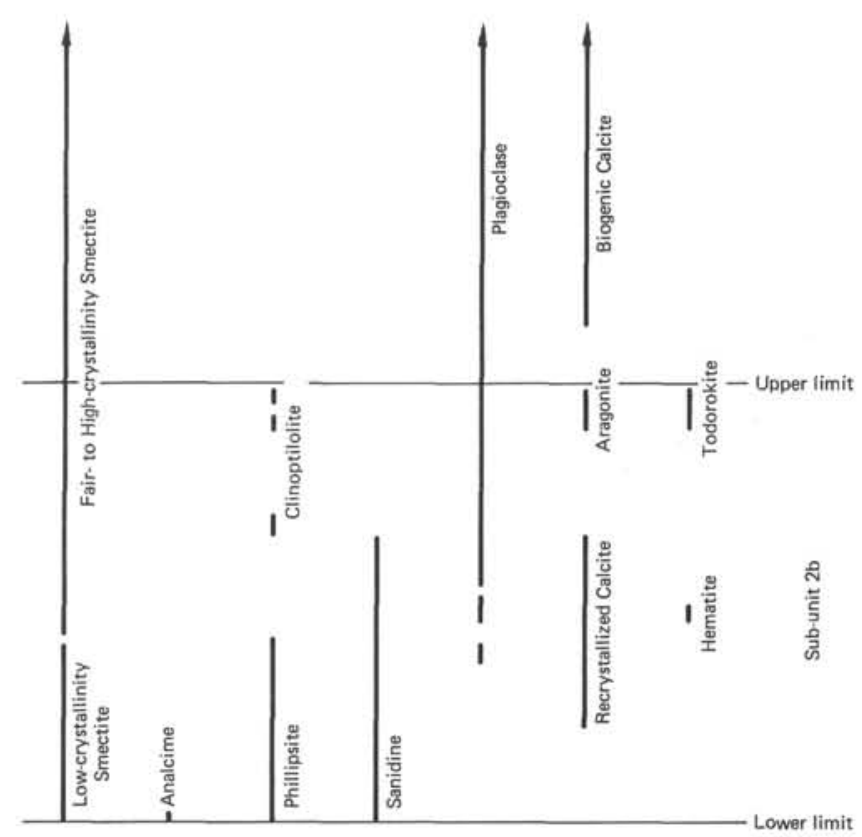

Figure 4. Schematic mineral paragenesis found at different levels at basal Site 450 . 
upper boundary of the altered zone and eventually disappears about $200 \mathrm{~cm}$ above contact with the basalt. Plagioclase is unstable in hydrothermal conditions, the more calcium-rich varieties being the less resistant. Experimental work has demonstrated that plagioclase transforms to other minerals or is completely destroyed at temperatures of about $200^{\circ} \mathrm{C}$ (Deer et al., 1967). Its disappearance in Hole 450 might suggest that temperatures as high as $200^{\circ} \mathrm{C}$ affected the tuffs up to 2 meters above the intrusive contact (Fig. 3). Minerals that may derive from the alteration of plagioclase will be discussed later.

\section{Carbonates}

Biogenic, low-Mg calcite disappears in the altered zone, where recrystallized spar calcite and euhedral to subhedral aragonite occur. Aragonite-bearing layers overlie the calcite ones (Fig. 4), suggesting that different authigenic carbonates can form depending on temperatures or on concentration of $\mathrm{Mg}$ ions (Bishoff and Fyfe, 1968; Natland, 1973). Etching on aragonite crystals may indicate that this mineral is not stable under the present conditions. The recrystallized lumps of calcite should reflect high rates of precipitation for this mineral. They might derive from hydrothermal dissolution of previous skeletal carbonates (Castellarin and Sartori, 1978) with subsequent reprecipitation, but they could come at least in part from the precipitation of the $\mathrm{Ca}$ released from glass and from anorthite-rich plagioclase. High amounts of carbonates in our altered interval suggest that under hydrothermal conditions neomorphic calcite may form (Bonatti, 1966) and replace previous volcaniclastic beds (Hein and Scholl, 1978).

\section{Smectite}

Dioctahedral smectite is present in all samples. Amounts and crystallinity do not vary significantly except for the lowermost 2 meters of the altered interval, where crystallinity is lower than that above (Fig. 3). In the same bottom interval phillipsite is present. Smectite derives from low-temperature devitrification of glass, and its decrease in crystallinity close to the intrusive contact might be explained by either of these two hypotheses:

\section{Hydrothermalism}

The tuffs already had a low-temperature smectite component when they underwent the hydrothermal process. Dioctahedral smectites are unstable in hydrothermal conditions and transform to other clay minerals and mixed layers above $300^{\circ} \mathrm{C}$ (Eberl et al., 1978). We can hypothesize that the hydrothermalism affected these phyllosilicates by decreasing their crystallinity. Lack of further transformation would suggest that the altered tuffs underwent temperatures significantly lower than $300^{\circ} \mathrm{C}$. In conditions unfavorable for smectite formation, phillipsite authigenesis could have been enhanced (see the following).

\section{Halmyrolisis}

Smectite formed at Site 450 after the emplacement and cooling of the basalt. It found favorable conditions everywhere in the tuff sequence except for the basal 2 meters, where the peculiar physiochemical setting of basalt halmyrolisis favored the formation of phillipsite. According to Hay (1978), the activity of dissolved species such as $\mathrm{H}+$, alkali ions, etc., determines whether a clay mineral or a zeolite is formed from alteration of tuffs.

\section{Zeolites}

From the intrusive contact upward in the altered interval, we observe the following sequence of zeolites: analcime (scarce) + phillipsite $\rightarrow$ phillipsite $\rightarrow$ clinoptilolite (Fig. 4). The trend is to a progressive hydration of the authigenic zeolites far from the heat source, which suggests that a thermal gradient might have been established in the intruded tuff sequence. In hydrothermal conditions, analcime starts forming at higher temperatures than phillipsite $\left(250^{\circ}\right.$ and $200^{\circ} \mathrm{C}$ in Höller and Wirshing, 1974, 1978; Wirsching, 1975), and clinoptilolite forms at lower temperatures (about $140^{\circ} \mathrm{C}$ in Hawkins et al., 1978). Such temperatures are in good accordance with the paragenesis found in Sub-unit 2b, because plagioclase (which is destroyed at about $200^{\circ} \mathrm{C}$, as is discussed earlier) coexists with clinoptilolite and disappears where phillipsite is present (Fig. 4). Plagioclase should be at least in part the precursor of zeolite. The relationship between phillipsite and low-crystallinity smectite at the bottom of Hole 450 suggests, however, that some of this zeolite might also derive directly from glass (in conditions unfavorable to smectite formation) or from previously formed smectite.

\section{Sanidine}

Authigenic sanidine is not necessarily a high-temperature mineral. Apart from data reported by Stewart et al. (1973), most of the known occurrences of this mineral are diagenetic in origin (see Kastner and Stonecipher, 1978). Moreover, authigenic sanidine has been experimentally formed at temperatures below $80^{\circ} \mathrm{C}$ by Flehmig (1977). In Site 450 (and also in Hole 447A), sanidine does not show great variation in concentration. Confined and extending throughout the altered zone, sanidine thus differs from phillipsite and low-crystallinity smectite (Fig. 4). It can also coexist with partly altered plagioclase. These observations suggest that sanidine might have formed in Site 450 at relatively low temperatures, deriving mostly from glass and subordinately from plagioclase. In fact, our samples of sanidine approach pure composition very closely, as is the case for authigenic $\mathrm{K}$ feldspars replacing former glass. Sanidine after plagioclase should be rich in $\mathrm{Na}$ according to Deer et al. (1967).

\section{Todorokite and Hematite}

These minerals, together with the amorphous ferromanganese compounds detected in smear slides, suggest a direct supply of $\mathrm{Fe}$ and $\mathrm{Mn}$ from alteration of the underlying basalt. Todorokite occurs higher in Sub-unit $2 \mathrm{~b}$ than in hematite, suggesting that some fractionation processes have occurred between the $\mathrm{Fe}$ and the more mobile Mn (Krauskopf, 1957). The presence of diagenetic crystalline hematite has been observed in the basal 
sediments of the West Philippine Basin by Bonatti et al. (1979). A diagenetic mobilization and recrystallization of hematite and todorokite in our samples would be indicated by their occurrence in blebs and mottles.

\section{CONCLUSIONS}

The authigenic minerals contained in the altered basal intervals of volcaniclastic sediments from Sites 447 and 450 of DSDP Leg 59 are dioctahedral smectite (with variable crystallinity), phillipsite, and sanidine. Sanidine seems the most widespread and common product of basal alteration in the marginal basins of the Philippine Sea.

The neomorphic mineral suites may have been produced by (1) halmyrolisis of the volcaniclastic sediments; (2) halmyrolisis of the underlying basalts; or (3) hydrothermalism associated with basaltic emplacement and cooling.

At Site 450, where other authigenic minerals occur (carbonates, analcime, clinoptilolite, Fe-Mn oxides), the basal paragenesis is consistent with a hydrothermal origin. Such a process could have produced temperatures up to $200^{\circ} \mathrm{C}$ in tuffs lying as high as 2 meters above the contact with a basaltic intrusion. Products of low-temperature alteration, however, are also present in the altered intervals of this site.

\section{ACKNOWLEDGMENTS}

E. Bonatti read parts of the manuscript and offered useful suggestions. N. Morandi discussed some aspects of alteration of volcaniclastics. G. Busatti and W. Landuzzi made laboratory analyses, and G. Zini drew the illustrations.

\section{REFERENCES}

Biscaye, P. E., 1965. Mineralogy and sedimentation of Recent deepsea clay in the Atlantic Ocean and adjacent seas and oceans. Geol. Soc. Am. Bull., 76:803-832.

Bishoff, J. L., and Fyfe, W. S., 1968. Catalysis, inhibition and the calcite-aragonite problem. Am. J. Sci., 266:65-79.

Bonatti, E., 1966. Deep sea authigenic calcite and dolomite. Science, 153:154.

, 1975. Metallogenesis at oceanic spreading centers. Ann. Rev. Earth Planet. Sci., 3:401-431.

Bonatti, E., Kolla, V., Moore, W. S., et al., 1979. Metallogenesis in marginal basins: Fe-rich basal deposits from the Philippine Sea. Mar. Geol. 32:21-37.

Castellarin, A., and Sartori, R., 1978. Quaternary iron-manganese deposits and associated pelagic sediments (radiolarian clay and chert, gypsiferous mud) from the Tyrrhenian Sea. Sedimentology, 25:801-821.

Cook, H. E., Johnson, P. D., Matti, J. C., et al., 1975. Methods of sample preparation and X-ray diffraction data analysis, X-ray mineralogy laboratory, Deep Sea Drilling Project, University of California, Riverside. In Hayes, D. E., Frakes, L. A., et al., Init. Repts. DSDP, 28: Washington (U.S. Govt. Printing Office), 999-1007.

Deer, W. A., Howie, R. A., and Zussman, J., 1967. Rock Forming Minerals (Vol. 4): London (Longman, Green \& Co.).

Eberl, D., Whitney, G., and Khoury, H., 1978. Hydrothermal reactivity of smectite. Am. Mineralogist, 63:401-409.

Flehmig, W., 1977. The synthesis of feldspars at temperatures between $0^{\circ}-80^{\circ} \mathrm{C}$, their ordering behavior and twinning. Contrib. Mineral. Petrol., 65:1-9.

Hawkins, D. B., Sheppard, R. A., and Gude, A. J., 1978. Hydrothermal synthesis of clinoptilolite and comments on the assemblage phillipsite-clinoptilolite-mordenite. In Sand, L. B., and Mumpton, F. A. (Eds.), Natural Zeolites. Occurrence, Properties, Use: Oxford (Pergamon Press), 337-343.

Hay, R. L., 1978. Geologic occurrences of zeolites. In Sand, L. B., and Mumpton, F. A., (Eds.), Natural Zeolites. Occurrence, Properties, Use: Oxford (Pergamon Press), 135-143.

Hein, J. R., and Scholl, D. W., 1978. Diagenesis and distribution of late Cenozoic volcanic sediments in the southern Bering Sea. Geol. Soc. Am. Bull., 89:197-210.

Höller, H., and Wirsching, U., 1974. Experimente zur Zeolithbildung durch hydrothermale Umwandlung. Contrib. Mineral. Petrol., 46:49-60.

, 1978. Experiments on the formation of zeolites by hydrothermal alteration of volcanic glasses. In Sand, L. B., and Mumpton, F. A. (Eds.), Natural Zeolites. Occurrence, Properties, Use: Oxford (Pergamon Press), 329-336.

Hummel, K., 1922. Die Entstehung eisenreicher Gesteine durch Halmyrolyse (= submarine Gesteinsersetzung). Geol. Rundschau, $13: 40-136$.

Kastner, M., and Stonecipher, S. A., 1978. Zeolites in pelagic sediments of the Atlantic, Pacific and Indian Oceans. In Sand, L. B., and Mumpton, F. A. (Eds.), Natural Zeolites. Occurrence, Properties, Use: Oxford (Pergamon Press), 199-220.

Krauskopf, K. B., 1957. Separation of manganese from iron in sedimentary processes. Geochim. Cosmochim. Acta, 12:61-84.

Natland, J. H., 1973. Basal ferromanganoan sediments at DSDP Site 183, Aleutian Abyssal Plain, and Site 192, Meiji Guyot, Northwest Pacific, Leg 19. In Creager, J. S., Scholl, D. W., et al., Init. Repts. DSDP, 19: Washington (U.S. Govt. Printing Office), 629-636.

Stewart, R. J., Natland, J. H., and Glassley, W. R., 1973. Petrology of volcanic rocks recovered on DSDP Leg 19 from the North Pacific Ocean and the Bering Sea. In Creager, J. S., Scholl, D. W., et al., Init. Repts. DSDP, 19: Washington (U.S. Govt. Printing Office), 615-627.

Wirsching, U., 1975. Experimente zum Einfluss des GesteinsglasChemismus auf die Zeolithbildung durch hydrothermale Umwandlung. Contrib. Mineral. Petrol., 49:117-124. 